\title{
Comparison of DNA extraction protocols to detect Mycobacterium bovis in bovine tissue by PCR
}

\section{Comparação de protocolos de extração de DNA para detectar Mycobacterium bovis em tecido bovino por PCR}

\author{
Cássia Yumi Ikuta ${ }^{1 *}$; Daniella Carvalho Ribeiro Oliveira ${ }^{1}$; Gisele Oliveira de \\ Souza $^{1}$; Antonio Francisco de Souza Filho ${ }^{3}$; José Henrique Hildebrand Grisi-Filho²; \\ Marcos Bryan Heinemann²; José Soares Ferreira Neto²
}

\begin{abstract}
The current scenario of international beef trading has increased the pressure for better and faster diagnosis of bovine tuberculosis. Although traditional culture remains the gold standard method to confirm Mycobacterium bovis infection, it is exceedingly time consuming, and demands viable mycobacteria. Molecular methods overcome the flaws of the bacteriological methods with faster detection and identification. However, mycobacterial features like a complex cell wall and pathogenhost interaction make the molecular detection a challenge. Three protocols for DNA extraction (A, $\mathrm{B}$ and $\mathrm{C}$ ) from bovine tissues were tested to verify the most suitable technique for routine diagnostic assessment of their specificity and sensitivity. Thirty culture-positive and thirty culture-negative granulomatous lesions were included in the trial. From each sample, three tissue suspensions at different dilutions $\left(10^{-1}, 10^{-2}\right.$ and $\left.10^{-3}\right)$ were prepared and submitted to DNA extraction. PCR procedures targeting IS6110 were performed, employing two volumes of DNA: $5 \mu \mathrm{L}$ of all three dilutions, and $2.5 \mu \mathrm{L}$ of the $10^{-1}$ dilution. Protocol A was able to detect members of the M. tuberculosis complex in most samples. The sensitivity of the test decreased with increase in tissue-suspension dilution. Although Protocol A presented the highest sensitivity followed by $\mathrm{C}$ and $\mathrm{B}$, it showed the lowest specificity, which can be due to a failure in primary isolation caused by the lack of viable organisms or incubation time. Regardless classical bacteriological methods are still recommended by OIE, after evaluating the sensitivity of DNA extraction protocols and PCR procedures, we conclude that the best strategy for M. bovis detection is to follow Protocol A on concentrated tissue suspensions.
\end{abstract}

Key words: DNA extraction. Bovine tissue. Bovine tuberculosis. Mycobacterium bovis. PCR.

\section{Resumo}

$\mathrm{O}$ atual comércio internacional de carne tem aumentado a pressão para haver um melhor e mais rápido diagnóstico de tuberculose bovina. O tradicional cultivo continua a ser o método padrão ouro para confirmar a infecção por Mycobacterium bovis, apesar de ser excessivamente demorado e necessitar de micobactérias viáveis. Métodos moleculares representam a superação de todos os defeitos dos métodos bacteriológicos com detecção e identificação mais rápidas. Entretanto, características das micobactérias, como uma complexa parede celular e a interação patógeno-hospedeiro, torna-os um desafio. Três

\footnotetext{
1 Pesquisadores, Faculdade de Medicina Veterinária e Zootecnia, Universidade de São Paulo, USP, São Paulo, SP, Brasil. E-mail: cassiayi@yahoo.com.br; daniella.peixeboi@gmail.com; ginutri@usp.br

2 Profs., Faculdade de Medicina Veterinária e Zootecnia, USP, São Paulo, SP, Brasil. E-mail: grisi@vps.fmvz.usp.br; marcosbryan@ usp.br; jsoares@vps.fmvz.usp.br

3 Discente, Curso de Doutorado do Epidemiologia Experimental aplicada às Zoonoses. Faculdade de Medicina Veterinária e Zootecnia, USP, São Paulo, SP, Brasil. E-mail: antoniosouzafilho@gmail.com

* Author for correspondence
} 
protocolos de extração de DNA (A, B e C) foram testados em tecidos bovinos para verificar qual técnica é mais adequada para diagnóstico de rotina, avaliando sua especificidade e sensibilidade. Trinta lesões granulomatosas positivas no cultivo e 30 lesões granulomatosas negativas no cultivo foram utilizadas no experimento. A partir de cada amostra, três homogeneizados com diferentes diluições $\left(10^{-1}, 10^{-2} \mathrm{e}\right.$ $10^{-3}$ ) foram preparadas e submetidas à extração de DNA. A PCR para o gene alvo IS6110 foi realizada empregando-se dois volumes de DNA: um com $5 \mu \mathrm{L}$ para todas as três diluições e outro com $2,5 \mu \mathrm{L}$ da diluição $10^{-1}$. O Protocolo A foi capaz de detectar membros do complexo M. tuberculosis na maior parte das amostras. À medida que a diluição dos homogeneizados aumentou, a sensibilidade diminuiu. Embora o Protocolo A tenha apresentado a maior sensibilidade, seguido por C e B, este revelou a menor especificidade, que pode ser devido à insuficiência de organismos viáveis ou tempo de incubação no primo isolamento. Apesar de os métodos bacteriológicos clássicos ainda serem recomendados pela OIE, através da avaliação da sensibilidade dos protocolos de extração de DNA e dos procedimentos de PCR, concluímos que a melhor estratégia para a detecção de $M$. bovis é usar o Protocolo A em homogeneizados mais concentrados.

Palavras-chave: Extração de DNA. Tecido bovino. Tuberculose bovina. Mycobacterium bovis. PCR.

\section{Introduction}

Bovine tuberculosis, caused by Mycobacterium bovis, is a chronic zoonosis responsible for elevated losses in a livestock-based economy (POLLOCK et al., 2006). Recent studies in 13 states of Brazil that contain $75 \%$ of the Brazilian cattle population, revealed prevalence of tuberculosis-infected herds between 0.36\%, in the Federal District, and 9.0\%, in São Paulo (BAHIENSE et al., 2016; BARBIERI et al., 2016; DIAS et al., 2016; GALVIS et al., 2016; GUEDES et al., 2016; LIMA et al., 2016; NÉSPOLI et al., 2016; QUEIROZ et al., 2016; RIBEIRO et al., 2016; ROCHA et al., 2016; SILVA et al., 2016; VELOSO et al., 2016; VENDRAME et al., 2016).

Current trading and transportation between countries have increased the pressure for better and faster diagnosis. The definitive diagnosis requires detection of $M$. bovis through bacteriological examination, as traditional culture remains the gold standard method for routine confirmation of infection (OIE, 2009). The most significant disadvantage of this method is the time consumed, since isolation may demand more than 12 weeks (CORNER et al., 2012), and biochemical identification can extend this time even further (COLLINS et al., 1982). Moreover, the number of viable mycobacteria might decrease through inadequate handling of tissues (WARDS et al., 1995) and decontamination procedures (CORNER et al., 2012), which may lead to false-negative results.

As faster alternatives, tests based on polymerase chain reaction (PCR) have been widely employed for mycobacterial identification (TELENTI et al., 1993; PARSONS et al., 2002; SALES et al., 2014a, 2014b), mostly using cultured isolates.

The application of molecular methods on clinical specimens encounters a number of problems, including a complex mycobacterial cell wall, the presence of the bacterial cell within a phagosome, a host cell and a granuloma, and the low amount of bacterial cells or DNA (KUMAR et al., 2010; RADOMSKI et al., 2013). Additionally, inhibitory substances present in the samples or the reagents used during DNA extraction, and an excessive amount of host DNA compared to the target DNA of the pathogen, also make accurate pathogen detection in clinical specimens difficult (PARK et al., 2014).

High sensitivity and specificity, simplicity, and reasonable cost are the necessary requirements for a routine diagnostic procedure. Despite the variety of available methods, there are no standards for bacterial DNA extraction from tissue samples. The aim of this study was to assess the specificity and sensitivity of three DNA extraction protocols to detect members of the M. tuberculosis complex (MTC) in bovine tissues. 


\section{Material and Methods}

From previously cultured granulomatous lesions (ROSALES RODRIGUEZ, 2005), we selected 30 samples identified as $M$. bovis and 30 samples that were negative for isolation. To confirm the prior negative results, the latter group was submitted to culture for a second time. The samples were decontaminated with $0.75 \%$ 1-hexadecylpyridinium chloride (AMBROSIO et al., 2008), inoculated into Stonebrink's and Löwenstein-Jensen's media, and incubated at $37{ }^{\circ} \mathrm{C}$ for up to 90 days (CENTRO PANAMERICANO DE ZOONOSIS, 1985).

Tissue suspensions were prepared by macerating one gram of each sample in $9 \mathrm{~mL}$ sterile $0.85 \%$ saline solution $\left(10^{-1}\right)$, and two 10 -fold dilutions, $10^{-2}$ and $10^{-3}$, were then made from the original suspension.

The DNA extraction methods were first tested using 1-2 colonies of $M$. bovis AN5 pure culture. DNA extraction procedures started with $400 \mu \mathrm{L}$ of tissue suspensions. The three dilutions of all 60 samples were submitted to the following protocols:

\section{Protocol A}

The tissue suspensions were pretreated with $100 \mu \mathrm{L}$ of lysozyme $\left(100 \mu \mathrm{g} \mathrm{mL}^{-1}\right)$ and $20 \mu \mathrm{L}$ of proteinase $\mathrm{K}\left(20 \mathrm{mg} \mathrm{mL}^{-1}\right)$ at $37^{\circ} \mathrm{C}$ for $1 \mathrm{~h}$. DNA extraction was then carried out as described by Boom et al. (1990).

\section{Protocol B}

The procedure was carried out as described by Zumárraga et al. (2001), except for the preparation of tissue suspensions described previously.

\section{Protocol C}

The DNA extraction procedure described by Santos et al. (1995) was modified. All tissue suspensions were centrifuged and the supernatant was discarded. The samples were incubated in 50 $\mu \mathrm{L}$ of $0.5 \mathrm{~N} \mathrm{NaOH}$ for $10 \mathrm{~min}$, and neutralized with $50 \mu \mathrm{L}$ of $1 \mathrm{M} \mathrm{NaH}_{2} \mathrm{PO}_{4}$. The suspension was centrifuged, and the pellet was resuspended in 60 $\mu \mathrm{L}$ of TE buffer (10 mM Tris-HCl, $1 \mathrm{mM}$ EDTA, $\mathrm{pH}$ 8.0) containing $1 \%$ Triton $\mathrm{X}-100$ and $50 \mu \mathrm{L}$ of proteinase $\mathrm{K}\left(10 \mathrm{mg} \mathrm{mL}^{-1}\right)$, followed by overnight incubation at $37^{\circ} \mathrm{C}$. Finally, the samples were submitted to three cycles of boiling for $10 \mathrm{~min}$ and freezing in liquid nitrogen for $2 \mathrm{~min}$.

All extracted DNA samples were stored at $-20^{\circ} \mathrm{C}$ until PCR assay. Detection of mycobacterial DNA was performed using the primers INS-1 (5'-CGTGAGGGCATCGAGGTGGC-3') and INS2 (5'-GCGTAGGCGTCGGTGACAAA-3'), which target the insertion element IS6110 (also known as IS986), and amplify a 245bp fragment that is observed in members of the MTC (HERMANS et al., 1990).

PCR mixture contained 1.25 U of Platinum Taq DNA Polymerase (Invitrogen, Carisbad, California, USA), 5X Green Go Taq ${ }^{\circledR}$ reaction buffer (Promega Corporation, Madison, WI, USA), $0.2 \mathrm{mM}$ dNTPs, 10 pmol of each primer, and sterilized ultrapure water to a final volume of $50 \mu \mathrm{L}$.

Two different volumes of DNA samples were used. Five microliters of all three dilutions and 2.5 $\mu \mathrm{L}$ of the $10^{-1}$ dilution were submitted to PCR. The amplified DNA was analyzed by $1 \%$ agarose gel electrophoresis and ethidium bromide staining ( 0.5 $\left.\mu \mathrm{g} \mathrm{mL} \mathrm{m}^{-1}\right)$.

\section{Results}

In order to compare each DNA extraction protocol, the tissue sample was considered as positive when the DNA template was amplified in at least one out of the four PCR procedures. Among the culture-positive tissue samples group, Protocol A presented $30(100 \%)$ positive results for MTC amplification, while Protocol B and $\mathrm{C}$ showed 14 (46.66\%) and $15(50 \%)$ positive results, respectively (Table 1). For the culture-negative group, Protocols A, B and C exhibited 20 (66.66\%), 12 (40\%), and 11 $(36.66 \%)$ positive samples, respectively (Table 2 ). 
Table 1. M. tuberculosis complex detection by PCR for M. bovis culture-positive group, according to DNA extraction protocols and homogenate dilutions.

\begin{tabular}{|c|c|c|c|c|c|c|c|c|c|c|c|c|}
\hline \multirow[b]{2}{*}{ DNA volume } & \multicolumn{4}{|c|}{ Protocol A } & \multicolumn{4}{|c|}{ Protocol B } & \multicolumn{4}{|c|}{ Protocol C } \\
\hline & $2.5 \mu \mathrm{L}$ & & $5 \mu \mathrm{L}$ & & $2.5 \mu \mathrm{L}$ & & $5 \mu \mathrm{L}$ & & $2.5 \mu \mathrm{L}$ & & $5 \mu \mathrm{L}$ & \\
\hline dilutions & $10^{-1}$ & $10^{-1}$ & $10^{-2}$ & $10^{-3}$ & $10^{-1}$ & $10^{-1}$ & $10^{-2}$ & $10^{-3}$ & $10^{-1}$ & $10^{-1}$ & $10^{-2}$ & $10^{-3}$ \\
\hline \multicolumn{13}{|l|}{ samples } \\
\hline $47 / 03$ & IP & II- & - & - & - & - & - & - & - & - & - & - \\
\hline $51 / 03$ & $\mathrm{P}$ & - & - & - & - & - & - & - & $\mathrm{P}$ & - & - & - \\
\hline $54 / 03$ & $\mathrm{P}$ & - & - & - & - & - & - & - & $\mathrm{P}$ & - & - & - \\
\hline $67 / 03$ & $\mathrm{P}$ & - & - & - & - & - & - & - & $\mathrm{P}$ & - & - & - \\
\hline $74 / 03$ & $P$ & - & - & - & - & - & - & - & - & - & - & - \\
\hline $75 / 03$ & $\mathrm{P}$ & - & - & - & - & - & - & - & - & - & - & - \\
\hline $80 / 03$ & $\mathrm{P}$ & $\mathrm{P}$ & $\mathrm{P}$ & - & - & - & - & - & - & - & - & - \\
\hline $81 / 03$ & $\mathrm{P}$ & - & - & - & - & - & - & - & - & - & - & - \\
\hline $85 / 03$ & $\mathrm{P}$ & - & - & - & - & - & - & - & - & - & - & - \\
\hline $92 / 03$ & $\mathrm{P}$ & - & $\mathrm{P}$ & - & - & - & - & - & $\mathrm{P}$ & - & - & - \\
\hline $112 / 03$ & $\mathrm{P}$ & $\mathrm{P}$ & - & - & $\mathrm{P}$ & - & - & - & - & $\mathrm{P}$ & - & - \\
\hline $126 / 03$ & $\mathrm{P}$ & $\mathrm{P}$ & - & - & - & - & - & - & - & - & - & - \\
\hline $127 / 03$ & $\mathrm{P}$ & - & $\mathrm{P}$ & - & - & - & - & - & - & - & - & - \\
\hline $129 / 03$ & $\mathrm{P}$ & $\mathrm{P}$ & - & - & - & - & - & - & - & - & - & - \\
\hline $142 / 03$ & $\mathrm{P}$ & $\mathrm{P}$ & - & - & $\mathrm{P}$ & - & - & - & - & - & - & - \\
\hline $167 / 03$ & $\mathrm{P}$ & $\mathrm{P}$ & $\mathrm{P}$ & - & $\mathrm{P}$ & $\mathrm{P}$ & $\mathrm{P}$ & $\mathrm{P}$ & $\mathrm{P}$ & $\mathrm{P}$ & - & - \\
\hline $209 / 03$ & $\mathrm{P}$ & $\mathrm{P}$ & - & - & - & - & - & - & - & - & - & - \\
\hline $215 / 03$ & $\mathrm{P}$ & $\mathrm{P}$ & $\mathrm{P}$ & - & $\mathrm{P}$ & $\mathrm{P}$ & $\mathrm{P}$ & $\mathrm{P}$ & $\mathrm{P}$ & $\mathrm{P}$ & - & - \\
\hline $224 / 03$ & $\mathrm{P}$ & $\mathrm{P}$ & $\mathrm{P}$ & - & - & - & $\mathrm{P}$ & $\mathrm{P}$ & - & - & - & - \\
\hline $256 / 03$ & - & $\mathrm{P}$ & - & - & $\mathrm{P}$ & - & - & - & - & - & - & - \\
\hline $278 / 03$ & $\mathrm{P}$ & $\mathrm{P}$ & $\mathrm{P}$ & - & - & - & $\mathrm{P}$ & - & - & - & - & - \\
\hline $288 / 03$ & $\mathrm{P}$ & $\mathrm{P}$ & $\mathrm{P}$ & $\mathrm{P}$ & $\mathrm{P}$ & $\mathrm{P}$ & - & - & - & $\mathrm{P}$ & - & - \\
\hline $295 / 03$ & $\mathrm{P}$ & $\mathrm{P}$ & - & - & - & - & - & - & $\mathrm{P}$ & $\mathrm{P}$ & - & - \\
\hline $319 / 03$ & $\mathrm{P}$ & $\mathrm{P}$ & $\mathrm{P}$ & - & $\mathrm{P}$ & $\mathrm{P}$ & $\mathrm{P}$ & - & $\mathrm{P}$ & - & - & - \\
\hline $325 / 03$ & $\mathrm{P}$ & $\mathrm{P}$ & $\mathrm{P}$ & - & $\mathrm{P}$ & - & $\mathrm{P}$ & - & $\mathrm{P}$ & - & - & - \\
\hline $338 / 03$ & $\mathrm{P}$ & $\mathrm{P}$ & - & - & $\mathrm{P}$ & $\mathrm{P}$ & - & - & $\mathrm{P}$ & $\mathrm{P}$ & - & - \\
\hline $339 / 03$ & $\mathrm{P}$ & $\mathrm{P}$ & - & $\mathrm{P}$ & $\mathrm{P}$ & $\mathrm{P}$ & - & - & $\mathrm{P}$ & - & - & - \\
\hline $356 / 03$ & $\mathrm{P}$ & $\mathrm{P}$ & $\mathrm{P}$ & $\mathrm{P}$ & - & - & - & - & - & - & - & - \\
\hline $407 / 03$ & $\mathrm{P}$ & $\mathrm{P}$ & - & - & $\mathrm{P}$ & $\mathrm{P}$ & - & - & $\mathrm{P}$ & - & - & - \\
\hline $414 / 03$ & $\mathrm{P}$ & $\mathrm{P}$ & $\mathrm{P}$ & - & $\mathrm{P}$ & $\mathrm{P}$ & $\mathrm{P}$ & $\mathrm{P}$ & $\mathrm{P}$ & - & - & - \\
\hline positives & $29 / 30$ & $20 / 30$ & $12 / 30$ & $03 / 30$ & $12 / 30$ & $08 / 30$ & $07 / 30$ & $04 / 30$ & $13 / 30$ & $06 / 30$ & $0 / 30$ & $0 / 30$ \\
\hline
\end{tabular}

I) positive; II) negative. 
Table 2. M. tuberculosis complex detection by PCR for M. bovis culture-negative group, according to DNA extraction protocols and homogenate dilutions.

\begin{tabular}{|c|c|c|c|c|c|c|c|c|c|c|c|c|}
\hline \multirow{3}{*}{$\begin{array}{l}\text { DNA volume } \\
\text { dilutions } \\
\text { samples }\end{array}$} & \multicolumn{4}{|c|}{ Protocol A } & \multicolumn{4}{|c|}{ Protocol B } & \multicolumn{4}{|c|}{ Protocol C } \\
\hline & \multicolumn{2}{|c|}{$2.5 \mu \mathrm{L}$} & \multicolumn{2}{|c|}{$5 \mu \mathrm{L}$} & \multirow{2}{*}{$\frac{2.5 \mu \mathrm{L}}{10^{-1}}$} & \multicolumn{3}{|c|}{$5 \mu \mathrm{L}$} & \multicolumn{2}{|c|}{$2.5 \mu \mathrm{L}$} & \multicolumn{2}{|l|}{$5 \mu \mathrm{L}$} \\
\hline & $10^{-1}$ & $10^{-1}$ & $10^{-2}$ & $10^{-3}$ & & $10^{-1}$ & $10^{-2}$ & $10^{-3}$ & $10^{-1}$ & $10^{-1}$ & $10^{-2}$ & $10^{-3}$ \\
\hline $05 / 02$ & $\mathrm{II}_{-}$ & IP & - & - & $\mathrm{P}$ & $\mathrm{P}$ & - & - & $\mathrm{P}$ & $\mathrm{P}$ & - & - \\
\hline $17 / 03$ & $\mathrm{P}$ & $\mathrm{P}$ & - & - & $\mathrm{P}$ & $\mathrm{P}$ & - & - & $\mathrm{P}$ & $\mathrm{P}$ & - & - \\
\hline $97 / 03$ & - & $\mathrm{P}$ & - & - & - & - & - & - & - & - & - & - \\
\hline $103 / 03$ & $\mathrm{P}$ & $\mathrm{P}$ & - & - & - & - & - & - & - & - & - & - \\
\hline $120 / 03$ & - & $\mathrm{P}$ & - & - & - & - & - & - & - & - & - & - \\
\hline $146 / 03$ & $\mathrm{P}$ & $\mathrm{P}$ & - & - & - & - & - & - & - & - & - & - \\
\hline $157 / 03$ & $\mathrm{P}$ & $\mathrm{P}$ & - & - & $\mathrm{P}$ & $\mathrm{P}$ & - & - & - & - & - & - \\
\hline $166 / 03$ & $\mathrm{P}$ & $\mathrm{P}$ & - & - & $\mathrm{P}$ & $\mathrm{P}$ & - & - & - & $\mathrm{P}$ & - & - \\
\hline $183 / 03$ & $\mathrm{P}$ & $\mathrm{P}$ & - & - & $\mathrm{P}$ & $\mathrm{P}$ & - & - & $\mathrm{P}$ & $\mathrm{P}$ & - & - \\
\hline $185 / 03$ & $\mathrm{P}$ & $\mathrm{P}$ & - & - & $\mathrm{P}$ & $\mathrm{P}$ & - & - & - & $\mathrm{P}$ & - & - \\
\hline $187 / 03$ & $\mathrm{P}$ & $\mathrm{P}$ & - & - & $\mathrm{P}$ & - & - & - & $\mathrm{P}$ & $\mathrm{P}$ & - & - \\
\hline $200 / 03$ & - & - & $\mathrm{P}$ & - & - & - & - & - & $\mathrm{P}$ & - & - & - \\
\hline $211 / 03$ & $\mathrm{P}$ & $\mathrm{P}$ & - & - & - & - & - & - & - & - & - & - \\
\hline $222 / 03$ & $\mathrm{P}$ & $\mathrm{P}$ & - & - & - & - & - & - & - & - & - & - \\
\hline $228 / 03$ & - & - & - & - & - & - & - & - & - & - & - & - \\
\hline $276 / 03$ & - & - & - & - & - & - & - & - & - & - & - & - \\
\hline $284 / 03$ & - & - & - & - & - & - & - & - & - & - & - & - \\
\hline $318 / 03$ & - & - & - & - & - & - & - & - & - & - & - & - \\
\hline $359 / 03$ & - & - & - & - & - & - & - & - & - & - & - & - \\
\hline $368 / 03$ & - & - & - & - & - & - & - & - & - & - & - & - \\
\hline $423 / 03$ & $\mathrm{P}$ & $\mathrm{P}$ & - & - & $\mathrm{P}$ & $\mathrm{P}$ & - & - & - & - & - & - \\
\hline $431 / 03$ & $\mathrm{P}$ & $\mathrm{P}$ & - & - & $\mathrm{P}$ & $\mathrm{P}$ & - & - & - & - & - & - \\
\hline $454 / 03$ & $\mathrm{P}$ & $\mathrm{P}$ & - & - & $\mathrm{P}$ & $\mathrm{P}$ & - & - & $\mathrm{P}$ & - & - & - \\
\hline $455 / 03$ & - & - & - & - & - & - & - & - & - & - & - & - \\
\hline $483 / 03$ & - & - & - & - & $\mathrm{P}$ & $\mathrm{P}$ & - & - & - & - & - & - \\
\hline $490 / 03$ & - & $\mathrm{P}$ & - & - & - & - & - & - & $\mathrm{P}$ & - & - & - \\
\hline $525 / 03$ & $\mathrm{P}$ & $\mathrm{P}$ & - & - & - & - & - & - & - & $\mathrm{P}$ & - & - \\
\hline $535 / 03$ & - & - & - & - & - & - & - & - & - & - & - & - \\
\hline $242 / 03$ & - & - & - & - & - & - & - & - & - & - & - & - \\
\hline $18 / 04$ & $\mathrm{P}$ & $\mathrm{P}$ & - & - & - & $\mathrm{P}$ & - & - & $\mathrm{P}$ & $\mathrm{P}$ & - & - \\
\hline positives & $15 / 30$ & $19 / 30$ & $01 / 30$ & $0 / 30$ & $11 / 30$ & $11 / 30$ & $0 / 30$ & $0 / 30$ & $08 / 30$ & $08 / 30$ & $0 / 30$ & $0 / 30$ \\
\hline
\end{tabular}

I) positive; II) negative.

As shown in Table 1 and 2, sensitivity decreased according to dilution, as the $10^{-1}$ dilution yielded better results than $10^{-2}$ and $10^{-3}$ dilutions. Overall, Protocol A presented the highest sensitivity, followed by Protocol C and B. Nevertheless, it displayed the lowest specificity (Table 3).
Regarding the DNA extraction protocol for tissue suspensions, Protocol A applied on a $10^{-1}$ dilution stood out from the others in terms of sensitivity (Figure 1). 
Table 3. Sensitivity and specificity of DNA extraction protocols for M. bovis.

\begin{tabular}{ccccccc}
\hline & \multicolumn{3}{c}{ Sensitivity (\%) } & \multicolumn{3}{c}{ Specificity (\%) } \\
\hline \multirow{2}{*}{ Point Estimate } & Lower 95\% & Upper 95\% & \multirow{2}{*}{ Point Estimate } & Lower 95\% & Upper 95\% \\
& & CL* & CL & & CL \\
\hline Protocol A & 100 & 88.43 & 100 & 33.33 & 17.29 & 52.81 \\
Protocol B & 46.67 & 28.34 & 65.67 & 60 & 40.60 & 77.34 \\
Protocol C & 50 & 31.30 & 68.70 & 63.33 & 43.86 & 80.07 \\
\hline
\end{tabular}

*confidence level.

Figure 1. Sensitivity of DNA extraction protocols and PCR procedures for M. bovis.

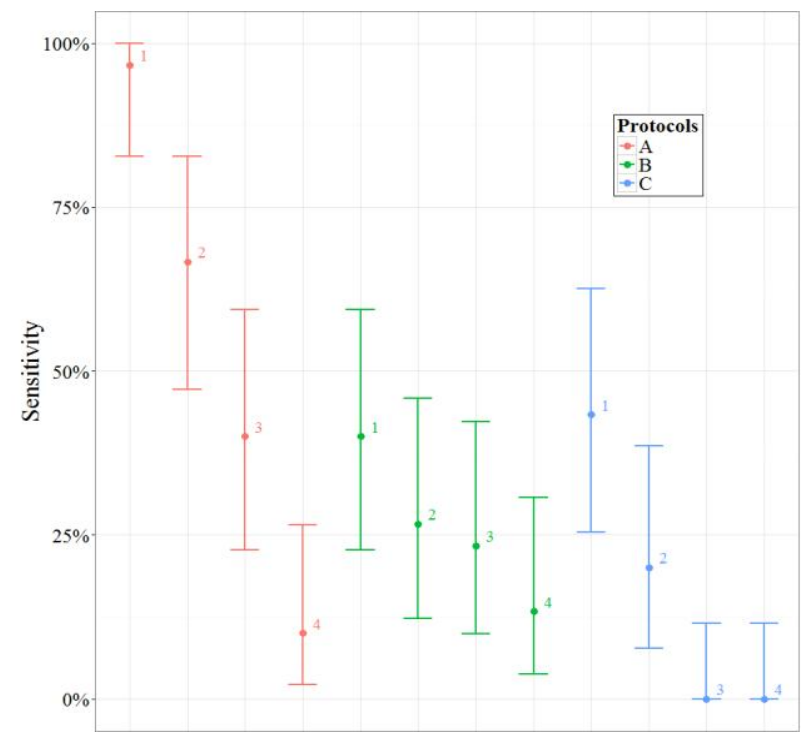

PCR procedures: 1) $2.5 \mu \mathrm{L}$ of $10^{-1}$ dilution; 2) $5 \mu \mathrm{L}$ of $10^{-1}$ dilution; 3) $5 \mu \mathrm{L}$ of $10^{-2}$ dilution; 4) $5 \mu \mathrm{L}$ of $10^{-3}$ dilution.

\section{Discussion}

Rapid detection of $M$. bovis infection has always been a matter of great importance, not only with respect to public health but also for animal health and economic issues. Several studies have been conducted to provide reliable and faster techniques to achieve this goal (LIÉBANA et al., 1995; WARDS et al., 1995; TAYLOR et al., 2007; CARDOSO et al., 2009).

The aftermath of PCR is subjected to the failure of extracting all the $M$. bovis organisms from tissue material, failure to extract DNA from $M$ bovis, presence of PCR inhibitors, or a combination of these (WARDS et al., 1995).
Despite the protocol described by Boom et al. (1990) was not developed to extract DNA from mycobacteria or mycobacteria from tissue, Protocol A revealed excellent sensitivity, possibly because of the modification of enzymatic addition, as observed by Wards et al. (1995).

Zanini et al. (2001) presented PCR-positive results for all culture-positive samples and for $60 \%$ of samples that failed to grow in culture. These results are almost identical to those obtained by Protocol A, yet questionable in terms of sensitivity and specificity, since the samples in this study were incubated for only 45 days, which could have considerably decreased their chances of being culture-positive. 
On the other hand, Liébana et al. (1995) incubated all samples for five months, and found $71.4 \%$ PCRpositive samples among the culture-positive and $6.25 \%$ among the culture-negative samples. In contrast to Protocol A and the one described by Zanini et al. (2001), Liébana et al. (1995) used only proteinase $\mathrm{K}$ and boiling for DNA extraction, which may have contributed to their PCR-negative results in culture-positive samples.

The low specificity observed in our findings was likely caused by the lack of an incubation period. Although the Manual of Diagnostic Tests and Vaccines for Terrestrial Animals 2015 of the World Organization for Animal Health (OIE) recommend 90 days of incubation, studies have shown that longer incubation periods increase the sensitivity of isolation (LIÉBANA et al.; 1995; CORNER et al., 2012).

Protocols B and C were performed as described by Zumárraga et al. (2001) and Santos et al. (1995), respectively, with few modifications. Both protocols were designed to extract mycobacterial DNA from tissues. Although our study reproduced similar results as reported by Santos et al. (1995), our findings were not similar to those found by Zumárraga et al. (2001), which observed M. bovis PCR-positive and culture-positive from all tissue samples.

Some tuberculous tissues contain considerable numbers of $M$. bovis, but it is common to find tissues with few of these organisms (WARDS et al., 1995). The low sensitivity observed in Protocol B may be due to lower tissue concentration, once the homogenates were prepared differently from the original (ZUMÁRRAGA et al., 2001).

Despite the number of $M$. bovis colonies seen after primary culture, and the efficiency of amplification had little relationship in some cases (WARDS et al., 1995), a minimum amount of DNA is still necessary for detection by PCR methods (TAYLOR et al., 2007), and most of PCR procedures with $10^{-2}$ and $10^{-3}$ dilutions of DNA exhibited poor sensitivity.
In addition, PCR sensitivity can be affected by the inhibitors present in the clinical samples, those from the reagents used in the extraction method, or the amount of extracted DNA (CARDOSO et al., 2009; RADOMSKI et al., 2013). Cardoso et al. (2009) demonstrated that the potential effect of PCR inhibitors can be reduced by diluting (1:2) or increasing the amount of DNA in the samples. In our study, the volume of $2.5 \mu \mathrm{L}$ for the $10^{-1}$ dilution of DNA submitted to PCR showed more positive samples than the volume of $5 \mu \mathrm{L}$ for the $10^{-1}$ dilution of DNA in the culture-positive group, and almost no difference was observed in the culture-negative group.

Molecular techniques have demonstrated high potential to identify more cases of $M$. bovis infection when compared with the conventional methods, especially for detecting nonviable organisms (WARDS et al., 1995). Direct PCR from lesion samples represents an additional tool in the routine diagnosis of bovine tuberculosis, as it is faster and is able to detect infection when culture methods are not sufficient (CARDOSO et al., 2009).

\section{Conclusion}

The findings of the present study indicate that Protocol A, as described by Boom et al. (1990) with the modification of prior enzymatic addition, should be the chosen DNA extraction protocol in the routine of detection of members of the $M$. tuberculosis complex in bovine tissues by PCR.

\section{Acknowledgements}

The authors acknowledge the financial support from CAPES, CNPq and FAPESP.

\section{References}

AMBROSIO, S. R.; OLIVEIRA, E. M. D.; RODRIGUEZ, C. A. R.; FERREIRA NETO, J. S.; AMAKU, M. Comparison of three decontamination 
methods for Mycobacterium bovis isolation. Brazilian Journal of Microbiology, Rio de Janeiro, v. 39, n. 2, p. 241-244, 2008.

BAHIENSE, L.; ÁVILA, L. N. de; BAVIA, M. E.; AMAKU, M.; DIAS, R. A.; GRISI-FILHO, J. H. H.; FERREIRA, F.; TELLES, E. O.; GONÇALVES, V. S. P.; HEINEMANN, M. B.; FERREIRA NETO, J. S. Prevalence and risk factors for bovine tuberculosis in the State of Bahia, Brazil. Semina: Ciências Agrárias, Londrina, v. 37, n. 5, p. 3549-3560, 2016. Suplemento 2.

BARBIERI, J. M.; OLIVEIRA, L. F.; DORNELES, E. M. S.; MOTA, A. L. A. A.; GONÇALVES, V. S. P.; MALUF, P. P.; FERREIRA NETO, J. S.; FERREIRA, F.; DIAS, R. A.; TELLES, E. O.; GRISI-FILHO, J. H. H.; HEINEMANN, M. B.; AMAKU, M.; LAGE, A. P. Epidemiological status of bovine tuberculosis in the state of Minas Gerais, Brazil, 2013. Semina: Ciências Agrárias, Londrina, v. 37, n. 5, p. 3531-3548, 2016. Suplemento 2.

BOOM, R.; SOL, C. J. A.; SALIMANS, M. M. M.; JANSEN, C. L.; WERTHEIM-VAN DILLEN, P. M. E.; VAN DER NOORDAA, J. Rapid and simple method for purification of nucleic acids. Journal of Clinical Microbiology, Washington, v. 28, n. 3, p. 495-503, 1990.

CARDOSO, M. A.; CARDOSO, R. F.; HIRATA, R. D. C.; HIRATA, M. H.; LEITE, C. Q. F.; SANTOS, A. C. B.; SIQUEIRA, V. L. D.; OKANO, W.; ROCHA, N. S.; LONARDONI, M. V. C. Direct detection of Mycobacterium bovis in bovine lymph nodes by PCR. Zoonoses and Public Health, Berlin, v. 56, n. 8, p. 46570, 2009.

CENTRO PANAMERICANO DE ZOONOSIS - CPZ. Tuberculosis. Bacteriologia de la tuberculosis: el cultivo del Mycobacterium tuberculosis. Buenos Aires: CPZ, 1985. (Nota técnica, 27).

COLLINS, C. H.; YATES, M. D.; GRANGE, J. M. Subdivision of Mycobaterium tuberculosis into five variants for epidemiological purposes: methods and nomenclature. The Journal of Hygiene, London, v. 89, n. 2, p. 235-242, 1982.

CORNER, L. A. L.; GORMLEY, E.; PFEIFFER, D. U. Primary isolation of Mycobacterium bovis from bovine tissues: conditions for maximising the number of positive cultures. Veterinary Microbiology, Amsterdam, v. 156, n. 1-2, p. 162-171, 2012.

DIAS, R. A.; STANOJLOVIC, F. M. U.; BELCHIOR, A. P. C.; FERREIRA, R. S.; GONÇALVES, R. C.; AGUIAR, R. S. C. B.; SOUSA, P. R.; SANTOS, A. M. A.; AMAKU, M.; FERREIRA, F.; TELLES, E. O.; GRISI-FILHO, J. H. H.; GONÇALVES, V. S. P.; HEINEMANN, M. B.;
FERREIRA NETO, J. S. Prevalence and risk factors for bovine tuberculosis in the state of São Paulo, Brazil. Semina: Ciências Agrárias, Londrina, v. 37, n. 5, p. 3673-3684, 2016. Suplemento 2.

GALVIS, J. O. A.; GRISI-FILHO, J. H. H; COSTA, D.; SAID, A. L. P. R.; AMAKU, M.; DIAS, R. A.; FERREIRA, F.; GONÇALVES, V. S. P.; HEINEMANN, M. B.; TELLES, E. O.; FERREIRA NETO, J. S. Epidemiologic characterization of bovine tuberculosis in the state of Espírito Santo, Brazil. Semina: Ciências Agrárias, Londrina, v. 37, n. 5, p. 3567-3578, 2016. Suplemento 2.

GUEDES, I. B.; BOTTENE, I. F. N.; MONTEIRO, L. A. R. C.; LEAL FILHO, J. M.; HEINEMANN, M. B.; AMAKU, M.; GRISI-FILHO, J. H. H.; DIAS, R. A.; FERREIRA, F.; TELLES, E. O.; GONÇALVES, V. S. P.; FERREIRA NETO, J. S. Prevalence and risk factors for bovine tuberculosis in the state of Mato Grosso do Sul, Brazil. Semina: Ciências Agrárias, Londrina, v. 37, n. 5, p. 3579-3588, 2016. Suplemento 2.

HERMANS, P. W. M.; VAN SOOLINGEN, D.; DALE, J. W.; SCHUITEMA, A. R. J.; McADAM, R. A.; CATTY, D.; VAN EMBDEN, J. D. A. Insertion element IS986 from Mycobacterium tuberculosis: a useful tool for diagnosis and epidemiology of tuberculosis. Journal of Clinical Microbiology, Washington, v. 28, n. 9, p. 20512058, 1990.

KUMAR, M.; SHARMA, S.; RAM, A. B.; KHAN, I. A. Efficient mycobacterial DNA extraction from clinical samples for early diagnosis of tuberculosis. The International Journal of Tuberculosis and Lung Disease, Paris, v. 14, n. 7, p. 847-851, 2010.

LIÉBANA, E.; ARANAZ, A.; MATEOS, A.; VILAFRANCA, M.; GOMEZ-MAMPASO, E.; TERCERO, J. C.; ALEMANY, J.; SUAREZ, G.; DOMINGO, M.; DOMINGUEZ, L. Simple and rapid detection of Mycobacterium tuberculosis complex organisms in bovine tissue samples by PCR. Journal of Clinical Microbiology, Washington, v. 33, n. 1, p. 33-36, 1995.

LIMA, P. B.; NASCIMENTO, D. L.; ALMEIDA, E. C.; PONTUAL, K. A. Q.; AMAKU, M.; DIAS, R. A.; FERREIRA, F.; GONÇALVES, V. S. P.; TELLES, E. O.; GRISI-FILHO, J. H. H.; HEINEMANN, M. B.; SILVA, J. C. R.; FERREIRA NETO, J. S. Epidemiological situation of bovine tuberculosis in the state of Pernambuco, Brazil. Semina: Ciências Agrárias, Londrina, v. 37, n. 5, p. 3601-3610, 2016. Suplemento 2.

NÉSPOLI, J. M. B.; NEGREIROS, R. L.; AMAKU, M.; DIAS, R. A.; FERREIRA, F.; TELLES, E. O.; HEINEMANN, M. B.; GRISI-FILHO, J. H. H.; 
GONÇALVES, V. S. P.; FERREIRA NETO, J. S. Epidemiological situation of bovine tuberculosis in the state of Mato Grosso, Brazil. Semina: Ciências Agrárias, Londrina, v. 37, n. 5, p. 3589-3600, 2016. Suplemento 2.

PARK, K. T.; ALLEN, A. J.; DAVIES, W. C. Development of a novel DNA extraction method for identification and quantification of Mycobacterium avium subsp. paratuberculosis from tissue samples by real-time PCR. Journal of Microbiological Methods, Amsterdam, v. 99, p. 58-65, 2014.

PARSONS, L. M.; BROSCH, R.; COLE, S. T.; SOMOSKÖVI, A.; LODER, A.; BRETZEL, G.; VAN SOOLINGEN, D.; HALE, Y. M.; SALFINGER, M. Rapid and simple approach for identification of Mycobacterium tuberculosis complex isolates by PCR-based genomic deletion analysis. Journal of Clinical Microbiology, Washington, v. 40, n. 7, p. 2339-2345, 2002.

POLLOCK, J. M.; RODGERS, J. D.; WELSH, M. D.; McNAIR, J. Pathogenesis of bovine tuberculosis: the role of experimental models of infection. Veterinary Microbiology, Amsterdam, v. 112, n. 2-4, p. 141-150, 2006.

QUEIROZ, M. R.; GROFF, A. C. M.; SILVA, N. S.; GRISI-FILHO, J. H. H.; AMAKU, M.; DIAS, R. A.; TELLES, E. O.; HEINEMANN, M. B.; FERREIRA NETO, J. S.; GONÇALVES, V. S. P. FERREIRA, F. Epidemiological status of bovine tuberculosis in the state of Rio Grande do Sul, Brazil. Semina: Ciências Agrárias, Londrina, v. 37, n. 5, p. 3647-3658, 2016. Suplemento 2.

RADOMSKI, N.; KREITMANN, L.; MCINTOSH, F.; BEHR, M. A. The critical role of DNA extraction for detection of mycobacteria in tissues. Plos One, San Francisco, v. 8, n. 10, p. e78749, 2013.

RIBEIRO, L. A.; GONÇALVES, V. S. P.; FRANCISCO, P. F. C.; MOTA, A. L. A. A.; NASCIMENTO, G. T.; LICURGO, J. B.; FERREIRA, F.; GRISI-FILHO, J. H. H.; FERREIRA NETO, J. S.; AMAKU, M.; DIAS, R. A.; TELLES, E. O.; HEINEMANN, M. B.; BORGES, J. R. J. Epidemiological status of bovine tuberculosis in the Federal District of Brazil. Semina: Ciências Agrárias, Londrina, v. 37, n. 5, p. 3561-3566, 2016. Suplemento 2.

ROCHA, W. V.; JAYME, V. S.; MOTA, A. L. A. A.; BRITO, W. M. E. D; PIRES, G. R. C; GRISI-FILHO, J. H. H; DIAS, R. A.; AMAKU, M.; TELLES, E. O.; HEINEMANN, M. B.; FERREIRA, F.; FERREIRA NETO, J. S.; GONÇALVES, V. S. P. Prevalence and herd-level risk factors of bovine tuberculosis in the State of Goiás, Brazil. Semina: Ciências Agrárias, Londrina, v. 37 , n. 5 , p. $3625-3628,2016$. Suplemento 2.
ROSALES RODRIGUEZ, C. A. Sistema de detecção de focos de tuberculose bovina no Estado de São Paulo utilizando métodos moleculares e epidemiológicos. 2005. Tese (Doutorado em Medicina Veterinária) - Faculdade de Medicina Veterinária e Zootecnia, Universidade de São Paulo, São Paulo.

SALES, M. L.; FONSECA JÚNIOR, A. A.; ORZIL, L.; ALENCAR, A. P.; HODON, M. A.; ISSA, M. A.; SOARES FILHO, P. M.; SILVA, M. R.; LAGE, A. P.; HEINEMANN, M. B. Validation of two real-time PCRs targeting the PE-PGRS 20 gene and the region of difference 4 for the characterization of Mycobacterium bovis isolates. Genetics and Molecular Research, Ribeirao Preto, v. 13, n. 2, p. 4607-4616, 2014a.

SALES, M. L.; FONSECA JÚNIOR, A. A.; SALES, E. B.; COTTORELLO, A. C. P.; ISSA, M. A.; HODON, M. A.; SOARES FILHO, P. M.; RAMALHO, A. K.; SILVA, M. R.; LAGE, A. P.; HEINEMANN, M. B. Evaluation of molecular markers for the diagnosis of Mycobacterium bovis. Folia Microbiologica, Praha, v. 59, n. 5, p. 433438, 2014b.

SANTOS, A. R.; GOES FILHO, J. T.; NERY, J. A. C.; DUPPRE, N. C.; GALLO, M. E. N.; SUFFYS, P. N.; DEGRAVE, W. M. Evaluation of PCR mediated DNA amplification in non-invasive biological specimens for subclinical detection of Mycobacterium leprae. FEMS Immunology and Medical Microbiology, Amsterdam, v. 11, p. 113-120, 1995.

SILVA, M. C. P.; GONCALVES, V. S. P.; MOTA, A. L. A. A.; KOLODA, M.; FERREIRA NETO, J. S.; GRISIFILHO, J. H. H; DIAS, R. A.; AMAKU, M.; TELLES, E. O.; FERREIRA, F.; HEINEMANN, M. B.; ALFIERI, A. A.; MULLER, E. E. Prevalence and herd-level risk factors for bovine tuberculosis in the state of Paraná, Brazil. Semina: Ciências Agrárias, Londrina, v. 37, n. 5, p. 3611-3624, 2016. Suplemento 2.

TAYLOR, G. M.; WORTH, D. R.; PALMER, S.; JAHANS, K.; HEWINSON, R. G. Rapid detection of Mycobacterium bovis DNA in cattle lymph nodes with visible lesions using PCR. BMC Veterinary Research, London, v. 3, id 12, 2007.

TELENTI, A.; MARCHESI, F.; BALZ, M.; BALLY, F.; BÖTTGER, E. C.; BODMER, T. Rapid identification of mycobacteria to the species level by polymerase chain reaction and restriction enzyme analysis. Journal of Clinical Microbiology, Washington, v. 31, n. 2, p. 175178, 1993.

VELOSO, F. P.; BAUMGARTEN, K. D.; MOTA, A. L. A. A.; FERREIRA, F.; FERREIRA NETO, J. S.; 
GRISI-FILHO, J. H. H.; DIAS, R. A.; AMAKU, M.; TELLES, E. O.; HEINEMANN, M. B.; GONÇALVES, V. S. P. Prevalence and herd-level risk factors of bovine tuberculosis in the State of Santa Catarina, Brazil. Semina: Ciências Agrárias, Londrina, v. 37, n. 5, p. 3659-3672, 2016. Suplemento 2.

VENDRAME, F. B.; AMAKU, M.; FERREIRA, F.; TELLES, E. O.; GRISI-FILHO, J. H. H.; GONÇALVES, V. S. P.; HEINEMANN, M. B.; FERREIRA NETO, J. S.; DIAS, R. A. Epidemiologic characterization of bovine tuberculosis in the State of Rondônia, Brazil. Semina: Ciências Agrárias, Londrina, v. 37, n. 5, p. 3639-3646, 2016. Suplemento 2.

WARDS, B. J.; COLLINS, D. M.; LISLE, G. W. Detection of Mycobacterium bovis in tissues by polymerase chain reaction. Veterinary Microbiology, Amsterdam, v. 43, n. 2-3, p. 227-240, 1995.
WORLD ORGANISATION FOR ANIMAL HEALTH

- OIE. Bovine tuberculosis. In: Manual of diagnostics tests and vaccines for terrestrial animals. [S.1.: s.n.], 2009. v. 1, pt. 2, sec. 2.4, chap. 2.4.7. Available at: $\quad<$ http://www.oie.int/fileadmin/Home/eng/Health standards/tahm/2.04.07_BOVINE_TB.pdf $>$. Accessed at: 20 out. 2015.

ZANINI, M. S.; MOREIRA, E. C.; LOPES, M. T. P.; OLIVEIRA, R. S.; LEÃO, S. C.; FIORAVANTI, R. L.; ROXO, E.; ZUMÁRRAGA, M.; ROMANO, M. I.; CATALDI, A.; SALAS, C. E. Mycobacterium bovis: polymerase chain reaction identification in bovine lymph node biopsies and genotyping in isolates from Southeast Brazil by spoligotyping and restriction fragment length polymorphism. Memórias do Instituto Oswaldo Cruz, Rio de Janeiro, v. 96, n. 6, p. 809-813, 2001.

ZUMÁRRAGA, M. J.; PAOLICCHI, F.; GARBACCIO, S.; GIOFFRÉ, A.; CATALDI, A. Aplicación de la PCR en la detección de Mycobacterium bovis en muestras de tejido de terneros. Veterinaria Argentina, Buenos Aires, v. 18, n. 179, p.668-676, 2001. 